\title{
On Deep History and the Brain
}




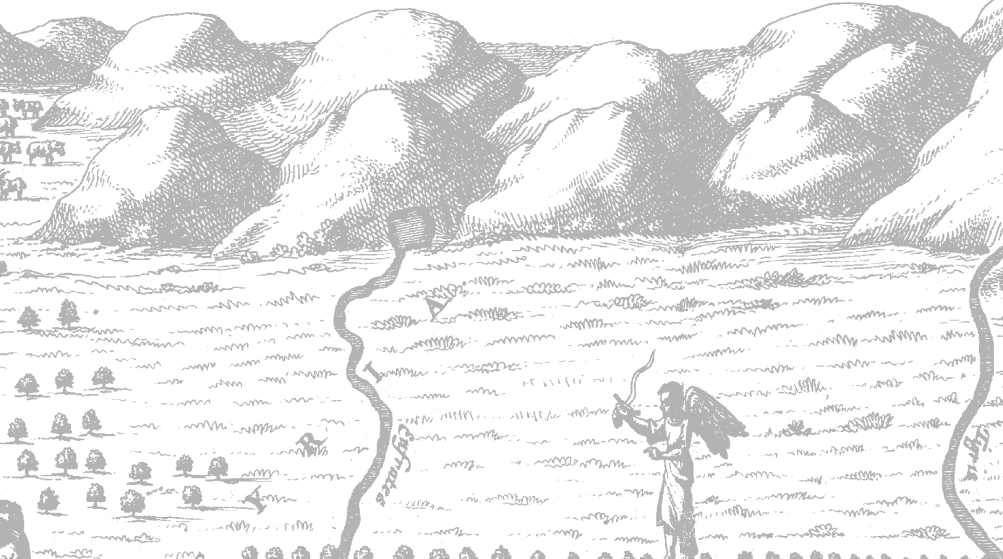

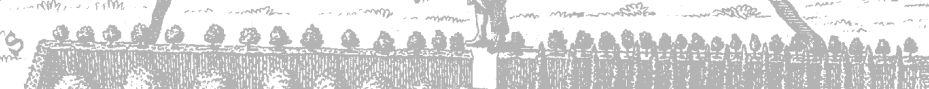

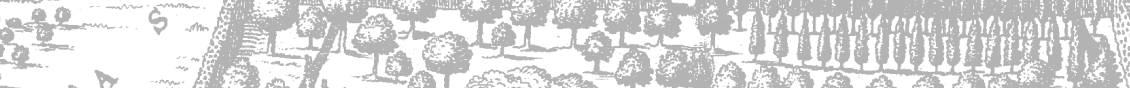

ARIVII

1.

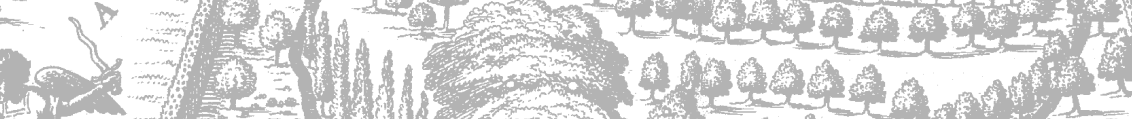

Sy-

(2)

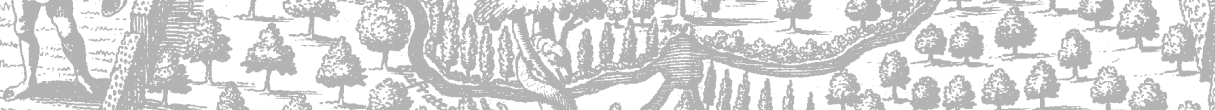

(1)

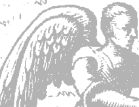
(2) (n)

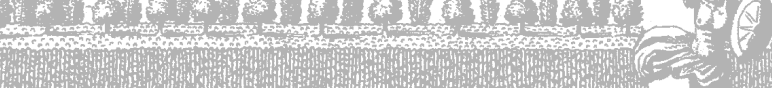

W.

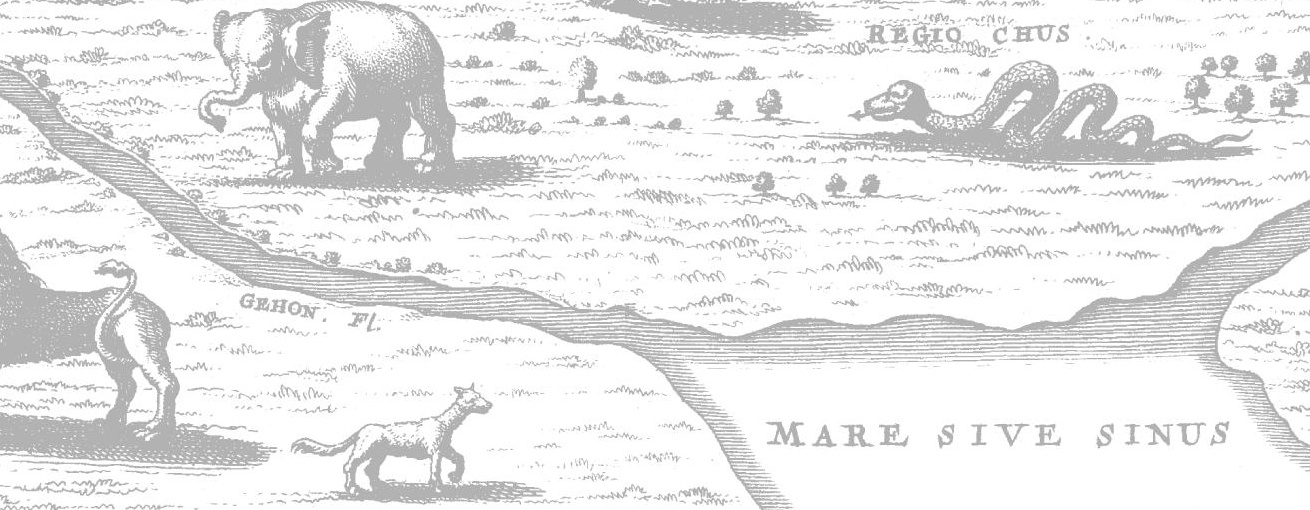




\section{On Deep History and the Brain}

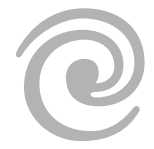

Daniel Lord Smail

\section{甲}

UNIVERSITY OF CALIFORNIA PRESS

Berkeley Los Angeles London 
The publisher gratefully acknowledges the generous contribution to this book provided by the Ahmanson Foundation Humanities Endowment Fund of the University of California Press Foundation.

\section{The publisher also gratefully acknowledges the support of the Harvard Historical Series.}

Cover illustration and frontispiece from Athanasius Kircher, Arca Nö̈, in tres libros digesta. Reproduced courtesy of the Houghton Library, Harvard University.

A Caravan Book

For more information, visit www.caravanbooks. org.

University of California Press, one of the most distinguished university presses in the United States, enriches lives around the world by advancing scholarship in the humanities, social sciences, and natural sciences. Its activities are supported by the UC Press Foundation and by philanthropic contributions from individuals and institutions. For more information, visit www.ucpress.edu.

University of California Press

Berkeley and Los Angeles, California

University of California Press, Ltd.

London, England

C 2008 by The Regents of the University of California

Library of Congress Cataloging-in-Publication Data

Smail, Daniel Lord.

On deep history and the brain / Daniel Lord Smail.

p. $\mathrm{cm}$.

Includes bibliographical references and index. ISBN: 978-0-520-25289-9 (cloth : alk. paper)

I. History-Philosophy. I. Title.

Di6.9.S62 2007

$90 \mathrm{I}-\mathrm{dc} 22$

2007 O I I 729

Manufactured in the United States of America

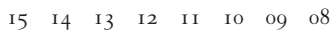

Iо $\quad \begin{array}{lllllllll}9 & 8 & 7 & 6 & 5 & 4 & 3 & 2 & \text { I }\end{array}$

The paper used in this publication meets the minimum requirements of ANSI/NIsO Z39.48-I992 (R I997) (Permanence of Paper). 
In memory of John R. W. Smail 
